\title{
The valuation of skill and the configuration of HRM
}

\section{MICHAEL RILEY AND EDITH SZIVAS}

Faculty of M anagement and Law, School of M anagement, U niversity of Surrey, G uildford GU27X H, UK.E-mail: m.riley@surrey.ac.uk; eszivas@surrey.ac.uk

This paper looks at the way skills and knowledge are valued by management in tourism and hospitality firms and at how that valuation is reflected in the configuration of human resources management (H RM) and the structure of labour markets. Based on a resource view of the firm and using the concepts of human resource architecture, it is argued that tourism and hospitality are not just examples of the internal spot-market mode in which acquisition dominates employment strategy, but rather constitute a special case in which the nature of labour productivity intervenes. The authors argue that labour is, in the main, separated from quantitative concepts of productivity and adds value only in qualitative terms. This sets up a dichotomy for human resource strategy between economic imperatives and the desire for quality. The resolution of that dichotomy, it is argued, is aggravated by the way individuals value their human capital, which has the effect of segmenting a general unskilled labour market and creating rigid occupational identities. This is the background against which modern ideas of HRM, such as employment flexibility, have to contend.

K eyw ords: human resource management; skill eval uation; productivity; employment flexibility

The purpose here is to argue, in conceptual terms, a case that the value placed on human capital in the tourism and hospitality industry creates and maintains a particular configuration of human resource management (HRM) within which there is a 'tension' between the need for labour productivity and the need for quality. The term configuration here refers to a rational set of policies, practices, strategic objectives and priorities that are concerned with the maintenance of a workforce. The paper creates a simple model that draws a line from the nature of a job through to the configuration of HRM. The overriding driver of the model is management's particular orientation towards skill evaluation. This evaluation, it will be argued, focuses on human capital and has three weighted components; the scarcity value of skill in the labour market, the measurability of that skill in terms of productivity and the contribution of the skill to competitive advantage. These concerns form an orientation or general attitude 
towards skill. The orientation towards skill sustains differentials between occupations, which, in turn, both reflects and maintains the microstructures of the labour market. After developing the simple model of the relationship between the nature of the job, the labour market and the configuration of HRM , the argument is extended to place tourism and hospitality HRM within the model. The arguments in support of its application to tourism and hospitality cite the inability of functional flexibility to become an embedded practice, high labour mobility and of evidence of occupational rigidity.

Before making a case for industry specificity, it would be appropriate to place the generic approaches in perspective. Briefly, there are numerous ways in which the practice of HRM can be analysed. Some models are based on generic disciplines such as managerial psychology and labour law and offer an explanation of HRM in behavioural and regulatory terms, respectively. The model described in this paper emphasizes the contribution of economic and technological influences. Prominent models include the core/periphery model, the resource-based approach, the competency model, the relational model and the learning model (Storey, 1995). Often, differences between models reflect the assumptions management makes about employee motivation: the so-called 'soft' and 'hard' models (Truss et al, 1997). For the most part, these models have been used in attempts to find a relationship between human resource policy and practice and organizational effectiveness under the banner of HRM being a source of competitive advantage (Michie and Sheehan, 2005). The results are very tentative, with positive findings confined to high-tech industries, Elsewhere, the issue as to how far these models actually represent reality is one which is constantly asked (D arrah, 1994; Caldwell, 2004). H owever, if the task is to explain the configuration of HRM in a particular industry or firm, then these generic models still apply as analytical templates at the firm level, but are limited in their capacity to explain differences at the industry level; therein lies the problem.

To tackle the issue of particular configurations of HRM related to specific industries requires a dual perspective on the nature of work in that specific industry. In other words, the concept of 'work' is evoked rather than that of 'employment'. On the one hand, there is the wide industry context. This exogenous view looks at the HRM of a firm in terms of its broad market, its labour market and how the firm's technological processes (work systems) fit into their market context. This perspective works from the outside in and traces influences through labour costs, market forces and human capital requirements. One the other hand, there is the micro perspective, the endogenous view, which works from the smallest unit of the system, that is, the individual, and works outwards. It starts at the point where the individual meets the organization, that is, at the psychological contract. This covert agreement based on unspoken assumptions places the concept of work directly into the employment relationship, and therefore into the direct focus of HRM (Rousseau, 1995). Based on assumptions about what each side expects, the 'individual deals', to use R ousseau's phase, is how managers and workers live together on a daily basis. Indeed, one definition of HRM simply might be that it has the function, through the paraphernalia of job descriptions, selection techniques, hiring standards, appraisal systems, etc, to make as explicit as possible the unspoken assumptions of the psychological contract. Townley (1993) argues that managerial 


\section{Weak internal labour market}

- Roughly specified hiring standards - Specific hiring standards

- Multiple ports of entry

- Low skill specificity

- No fixed promotion criteria

- Low organization commitment

- Pay differentials vary over time

\section{Observed behaviour}

- High labour turnover

- Managers do not value workforce stability

- Workers rely on mobility in the market to secure advancement

\section{Strong internal labour market}

- Single or restricted ports of entry

- Embedded on-the-job training

- Fixed promotion criteria

- Strong workplace culture and commitment

- Pay differentials remain constant

\section{Observed behaviour}

- Low levels of labour turnover

- Managers value workforce stability

- Workers value job security

- Workers expect advancement within the organization

Figure 1. The dimensions of an internal labour market.

expectations in the contract are based on the meaning of skill, which forms an ongoing dialogue with that of the individual worker; that continuous dial ogue Townley sees as part of HRM. However, this malleable microconcept is itself the product of wider and bigger forces. Both perspectives are different ways of looking at the same thing and should, in analysis, validate each other in that they point to the same configuration of HRM. W hat lies at the heart of both perspectives is the valuation of human capital. The value of human capital is, for the employer, the basis of their employment policies and, for the individual, the basis of their 'bargain' in the psychological contract. By using both perspectives, the analysis seeks to identify the main forces which determine the policies, practices and the daily life of HRM in a particular industry or firm.

\section{Developing a model that explains industry specificity}

\section{Skill valuation and the market context}

From the exogenous perspective, the principal assumption of the arguments is that economic and technological determinism work in tandem to form the configuration of HRM. The concept which embodies both these forces is that of the internal labour market (ILM) and its relationship to the external market. Figure 1 outlines the dimensions of the polar extremes of the concept of the ILM, together with the behaviour normally associated with these positions.

Although these two concepts are ideal types and it is possible to have less intense versions of both, the point is that they are not a continuum; they take contrary positions and management has to choose.

The main argument, therefore, is that, at a fundamental level, the configuration of HRM can be explained by the strength or weakness of the 
firm's ILM. The particular form of ILM is, in turn, explainable by technological specificity, that is, the uniqueness of the work undertaken by the firm, and the valuation of skill which follows from that (Doeringer and Piore, 1971). To illustrate by extremes, if a firm employs skills that are not unique and easily available in the market, then it is likely to deploy a weak internal market with numerous ports of entry; by contrast, if the firm uses unique skills, it is likely to close off ports of entry, train extensively, reward seniority and use formal criteria for promotion (the use of 'merit' as a criterion on its own and without clarification as to its meaning is associated with weak ILMs). In other words, keep the labour market out and horde what they have through a strong ILM. The concept of an ILM expresses the firm's relationship to the external markets and, in doing that, the form of the ILM represents the valuation of skill by managers. This idea is founded on the assumption that the type of work involved in a job determines the size and character of that job's external labour market, and therefore the firm's recruitment policy (Hage, 1989). It follows logically that the type of labour market the job falls into will be influenced by the perceived ease or difficulty with which the skill can be acquired (Rosen, 1972). This relationship between value and ease of acquisition becomes salient to HRM configurations because the way a firm values skills is reflected in the supply and demand conditions in the market. In a sense, it is a reciprocal relationship; perceptions of the market feed back into perceptions of skill. W here recruitment strategies meet assumptions about skill is in the general perception of the size of the market and its stability. Just assuming that there are many people with a particular skill might be enough to devalue it. Actual changes in the proportions of occupations in the market are not reflected directly in perceptions (Cully, 2002). Similarly, there are unseen consequences to job redesign. Psacharopoulos (1991) argues that the labour market can be seen as a learning vehicle and that any skill is founded on a trail of learning experiences: these trails form channels like faint scars on the surface of the market (Maillat, 1984). To change the content of a job is to alter, and maybe destroy, a learning phenomenon located, but unseen, in the labour market. Recognition of such changes would be apparent only over time.

$\mathrm{H}$ owever, it is the nature of technol ogical processes that determines the levels and type of human capital employed and skills and competences actually used. Spell (2001) examines the relationship between technological processes and skill requirements and argues that cognitive abilities, interpersonal skills and psychomotor skills link directly to information processing demands, the variety of human contacts and the degree of routine, respectively. He goes on to argue that HRM policies and practices such as form of control and incentives reflect these three particular requirements directly. In doing so, Spell connects technological processes directly to H RM. Lepak and Snell (1999) use the term 'HRM architecture' to describe HRM configurations. They centre their arguments on the mode of employment (the means by which a workforce is acquired) and differentiate four modes, all deriving ultimately from the valuation and the uniqueness of human capital, which are: internal development, acquisition, contracting and alliance - that is, grow your own, buy in the market, subcontract and share. These modes, they argue, carry with them different psychological contracts, each expressing specific employment relationships. $\mathrm{N}$ ordhaug (2004) also sees the relationship between technological specificity 
and mode of employment and adds the measurability of productivity to the equation. He argues that when the productivity of the individual worker is difficult to evaluate and where the relevant skills are available in the market, then the mode of HRM governance is that of an internal spot market. W hen the same conditions apply to a group, they form, what he calls, a primitive team. In both cases, the commitment to an employment relationship is weak and labour turnover high. By contrast, where skills are firm specific and productivity is measurable, then an obligational market forms; which is equivalent to a strong ILM. W here a combination of firm specific skills exists with a limited ability to measure productivity because of collective interdependent performance, then H R M has to govern, what he calls, a relational team. These concepts are captured through the notion of strong or weak ILMs.

The above theoretical analysis suggests that industries will have different H R M policies and practices because, in the eyes of their management, their skill and knowledge basis varies in scarcity and their productivity varies in terms of measurability. It does not say anything about the actual contribution to competitive advantage, other than suggesting that, in some circumstances, this is difficult to quantify. It is also worth pointing out at this juncture that these arguments do not deny the influence of the organizational size variable, which, it is argued, determines the scope and detail of HRM, but not its essential configuration. Fragmented organization structures such as those seen in tourism and hospitality create small subunits whereby HRM is delegated downwards to local management, with only policy guidance to act as a control.

Given the importance of mode of employment to HRM configuration, what matters is not any objective categorization of skill, but the attitudes of management towards skill. It is their orientation which activates the value system. They do not rethink that orientation every time a job vacancy occurs, but bring a set attitude to that recruitment problem (Adams and M CQuillan, 2000). In this sense, employment practices reflect general orientations towards skill, training, productivity and flexibility. The term 'skill' is essentially a social construction and, given technological progress, one which is al ways in transition (Payne, 2000). H owever, despite its many meanings and its capacity to be interpreted, there is a reality that can be expressed by a general attitude and inferred by length of time to full capacity (Penn et al, 1994). Here again, the ease of learning is salient to the arguments. If management see skills as being learnt easily, then that might promote a weak ILM. If, the work processes of a firm are seen as dependent on integrated teamwork, then that may promote social skills as a hiring criteria, as well as technical skills which, in turn, might promote a more stable ILM .

\section{A ttitudes to skill evaluation as an industry norm}

W hat is being argued here is that although management in general can develop a particular orientation towards skill, what matters is that the orientation can have consequences that are industry specific. Spender (1989) argues that where firms face similar problems, they find similar solutions, what he calls 'industry recipes'. Similarly, Phillips (1996) refers to mindsets within industry parameters. The relationship between a set of firms and their shared labour market is ripe for such normative behaviour. One focus of normative agreement 
would be pay differentials, and particularly the valuation of the same occupation across firms. The literature on comparable worth argues that even the most sophisticated job evaluation scheme is essentially subjective and riddled with biases (Tompkins, 1987; Arnault et al, 2001). The structures such schemes produce reflect, in the long run, market structure rather than current market conditions and the marginal productivity of a particular occupation. The sensitivity of such differentials to concerns about social worth is dependent on particular national culture and industrial relations systems (Levision et al, 2002).

\section{Skill valuation and productivity}

$\mathrm{N}$ otwithstanding the previous arguments about technological specificity and the measurability of productivity, there is the matter of labour productivity itself. The relationship of human capital to productivity is central to the skill debate. The conventional wisdom of the skills-productivity relationship, namely, that human capital matters to increasing productivity, is one which can be challenged. From the macro perspective, skills and knowledge are seen as a source of competitive advantage, and are therefore a focus of concern as to how the marketplace treats them. Conversely, endemic low levels of skill are seen as a barrier to economic growth - the low skills equilibrium (Booth and Snower, 1996). This perspective is mirrored at the micro level, but with the addition of the complication of having to address issues of quality. W hat lies behind the accepted wisdom on skills and productivity are the assumptions that skills contribute to productivity and that there are direct returns to productivity and training from investment in increasing human capital. Furthermore, the fact that quality is now seen as an integral part of productivity adds to the value of human capital and to the returns to the employer's investment. Under these conditions, it is in the interests of employers and workers to invest in training. Employers, it is hypothesized, should have a positive attitude towards training and any other form of skill development.

An alternative perspective on skill and productivity develops when the primary assumption of the conventional argument is replaced by one of assumed separation of human capital from productivity. To argue that a job is detached from productivity does not mean that it is unproductive, or that it has no utility. $\mathrm{N}$ or is it to imply that it requires no human capital - all jobs have some such requirement and separation can exist at any level of skill. Group tasks can also exhibit this separation. Furthermore, such jobs still can be within the remit of productivity processes, such as technological substitution. However, what is required is that the workflow of that job or group task be controlled directly by demand that is itself variable and difficult to predict. In other words, the normal ratio description of productivity whereby input causes output is reversed: output and, more specifically, the demand for output actually determine inputs. By way of illustration, two contrasting examples: in the first, a surgical team's high human capital is detached from output productivity unless an uninterrupted stream of patients exists and, in the second, at a lower level of skill, and again putting quality to one side, an experienced pizza maker's skill would be as productive as a novice at low demand levels and only attached to productivity as the restaurant nears capacity. In these examples, the pattern 
of demand arbitrates between productive capacity and productivity (Riley et al, 2002). In the case of tourism and hospitality, the degree of variability of consumer demand can be seen as a key determinant of labour productivity (Riley, 1999). The skill specificity and demand variation arguments come together most notably in the pricing of labour, which is a function of the valuation of human capital and the uncertainty of the anticipated need for variation in supply (Riley and Szivas, 2003). The basic argument is that when labour effort, in quantitative terms, is separated from productivity, then management's attention is focused on the overall cost of labour.

\section{The contribution of skill to compeitive advantage}

The literature on the contribution of human resource practices to competitive advantage emphasizes modern generic practices such as empowerment, incentives and flexible employment ( $\mathrm{H}$ abir and Larasati, 1999; Blount et al, 2005). H owever, whilst these practices are aimed at the development of new knowledge and skill, they do not in themselves radically change the skill base of an industry. Indirectly, they can be used to reduce labour turnover and even to horde valued skills if, that is, unique and valuable skills can be identified. $\mathrm{K}$ ang et al (2007) point out that once employee knowledge is valued, then it becomes a way of conceiving how the organization actually works creating differentials and structure which, they argue, leads towards competitive advantage.

One explanation for organizational variation of the same occupation is not so much that the jobs are radically different, but that they are valued differentially. The literature is not clear as to whether this is an evaluation of the job or the particular incumbent. An exceptional person can leave a historical trail which increases the value of the job for those who follow. Stinchcombe (1963) raises the issue of 'talent' and suggests that this personal quality can be valued through remuneration systems. W hat makes management value a particular skill or person may be a function of the cost of replacement, but also may be influenced by the 'development system' which produced that particular skill or person. This brings not only education and credentialism into the argument, but also the skill accumulation system and whether it is founded on a company scheme or left to the marketplace (Ladkin and Riley, 1996).

\section{The model}

Figure 2 displays the relationship between the specificity of a job, its market characteristics, the form of internal labour market and the mode of employment. The model shows how the nature of a job leads to assumptions about its labour market and how the appropriate skills are to be acquired. The force that maintains this model is the attitude of management towards skill evaluation. It is not a comprehensive model of HRM activities because it ends at and emphasizes the mode of recruitment of the firm. It must be said by justification that recruitment is the starting point of all HRM policies; incentives and development begin life with starting salaries and hiring standards. 


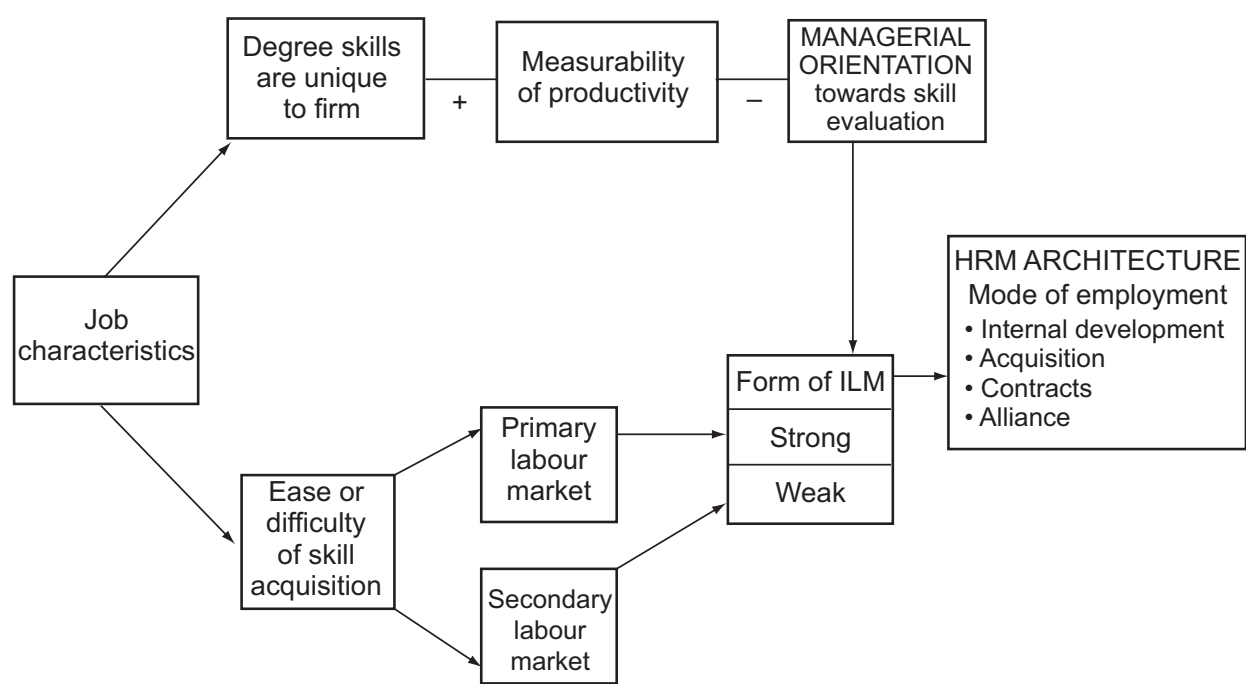

Figure 2. The configuration of job specificity and labour market character.

\section{The place of tourism and hospitality within the model}

The argument that tourism and hospitality has a particular configuration of HRM requires that it can be differentiated by industrial sector and that it is reasonably homogeneous within sectors. Riley et al (2000) argue the case that 'beneath' the people management and regulation frameworks, labour economics has an indirect but very immediate influence on the industry. W hat is perhaps harder to justify is the argument that the tourism and hospitality industry, with its inherent diversity, is sufficiently homogeneous to warrant the same form of HRM .

To justify homogeneity within surface diversity, the analysis needs to adopt a socio-technical approach. The industry has a variety of occupations, each with their own skill and knowledge requirements, which vary by level of human capital. H owever, there is a degree of commonality within this diversity. W hat do taxi drivers, waiters, passenger service agents and receptionists have in common? Firstly, the demand for their labour is variable and often random. W hen a particular dish is ordered that activates only part of a kitchen brigade; when a guest contemplates a snack in the coffee shop or ordering it from room service, the choice activates only one part of the labour force, leaving the other potentially idle; taking one excursion but not another can affect the productivity of a journey. In a lending library, the choice of book makes no difference to the work of the librarian, but in tourism and hospitality, choice affects workload directly. There is a relationship between the range of services and productivity. Secondly, they require social skill and a degree of cognitive skill to handle the complexity that comes with handling people and, finally, their outputs are evaluated subjectively. The argument is that these, and other tourism and hospitality occupations, share situations and experiences which give them similar priorities, for example, good service can be many things, but never slow; 
a tolerance of downtime and acceptance of work without a tangible end product (Riley et al, 2002, pp 61-69).

The non-direct service occupations, such as chefs and cleaners, have a production function related more to manufacturing processes but, even here, they cannot escape the effect of stochastic demand on their workload and the subjectivity of evaluation. Demand can be predictable, but simultaneously irregular. Translated into the psychological contract, this suggests that service industry contracts are imprecise as compared to routine manufacturing or bureaucratic white-collar occupations. The amount of imprecision in the psychological contract is decreed by the degree to which the work can be specified formally and the output measured objectively. HRM may try to make matters more explicit but complete description is impossible. This imprecision is commonly shared within the industry and across skill levels, firms and occupations. The argument is that technological determinism influences the precision of the psychological contract and, consequently, has implications as to how employees are managed. The more imprecise, the more normative the form of management control. It is on this basis, that psychological contracts will be imprecise, that the argument is made that configurations of HRM will be similar in tourism and hospitality firms.

In terms of the model described in Figure 2, the majority of jobs are fairly easy to learn and individual productivity does not increase with tenure, a fact that is reflected in the absence of seniority increments in pay systems (R iley and Szivas, 2003). This would place such jobs in the secondary labour market and would invite management to construct a weak ILM with spot-market acquisition and subcontracting as the main modes of employment. The pattern of demand requires flexibility at a time span much smaller than seasonality. In response to this, management appears to favour numerical flexibility based on a 'churn' of employees moving between the firm and the labour market. There is a literature of concern for 'high labour turnover'; this phenomenon is an example of where something can be simultaneously both a problem and a solution. For day-to-day management, labour turnover can be expensive in terms of cost and managerial energy, but it solves the problem of matching supply to variable demand. In other words, management has a problem, but economics have a solution. Empirical support for the model and the weak ILM comes indirectly from the incidence of high labour turnover and from evidence of the lack of formality in areas of hospitality and tourism HRM (Simms et al, 1988).

The human resource architecture school places the configuration of HRM firmly in the realm of business and labour economics and, in doing so, suggests that HRM cannot change unless the economics of the business or labour changes. In terms of labour economics, change requires some kind of major restructuring of occupations. In reality, this means that the only 'game in town' is functional flexibility.

\section{Framing the problem}

The problem for HRM in tourism and hospitality is twofold; there are the inherent issues and there is the tempting offer of generic solutions from the 
outside world. The inherent problems revolve around the form of diversity on which HRM policy is to be based and on attitudes towards quality. More specifically, the problems are:

- the fact of diversity of skill cannot be corralled so easily into a homogeneous lump of unskilled labour

- that, in reality, the skilled and the unskilled actually work together in service processes that might conform to N ordhaug's (2004) 'relational teams' (pilots and cabin staff; chefs and kitchen porters)

- that management is concerned with quality but recognize that it is problematic to productivity.

\section{Diversity}

Although it is clear that the majority of workers do jobs that can be learnt easily, the industry employs many skilled workers, technicians and managers. However, even those jobs identified by Nickson and Warhurst (2007) that require good social skills are, for the purposes of recruitment, based fundamentally on personal qualities, which has the effect of placing them in large, if not the same, secondary labour market as unskilled workers. More important is the fact that the unskilled form the majority and that they work in interdependent processes with skilled workers; that is the problem for H R M policy. Equity becomes a delicate balance in such circumstances, with the need to explain pay differentials paramount. Yet, this does not appear to happen; whatever differentials exist seem to be legitimized only by industrial culture. Only in unionized environments, such as airlines, is this balance achieved through formal job evaluation schemes (strong ILMs by another name). H owever, unionization does not decrease the effects of demand fluctuation, it only makes the response to it more formal. Riley (1993) outlines the way in which union agreements accommodate the need for flexibility. Such arrangements mirror labour market activity and, although they are more expensive, they release managers from the chore of daily spot-market intervention. The basic issue for HRM in tourism and hospitality is: does it manage holistically, treating the skilled and the unskilled the same, or does it have different approaches to both? There is some evidence that the retail industries, which have the same fragmented unit structure as tourism and hospitality, have improved HRM through having a holistic approach. HRM policy formation is influenced by the form of diversity it addresses.

Diversity management means having HRM policies pitched sufficiently wide to embrace equity but focused simultaneously on different characteristics of a workforce to ensure common identity and commitment to the organization. This means that such policies override what people actually do and must, by implication, be about the concept of 'employment' rather than 'work'. The idea of HRM, and particularly human resource development, does assume that firms have a degree of commitment to retaining staff because, without this, the term 'employment' is confined to its legal meaning. It could be argued, somewhat harshly, that tourism and hospitality manage diversity by letting the labour market do the managing. There is little meaningful planning beyond making migration arrangements (Lui and Wall, 2006), and much of the contingency management revolves around numerical flexibility and pay strategies (Riley, 
1990; I srael, 2007). Certainly, there is evidence that personal development is through self-initiated mobility rather than organizational initiative (Ladkin and Riley, 1996).

\section{The problem of quality}

It would be ridiculous to suggest that management is not concerned with quality and, although it is beyond the scope of this paper to go into detail, there exists a considerable literature on the management of quality. By far the strongest theme of this literature concerns management's attempts to prescribe and to measure quality where the concern is more for control than for productivity. Perhaps a more important theme is the tendency, in some areas, for management to 'throw bodies' at the concept of service (ranks of waiters, special airport lounges). This notion that more people makes for more luxury is founded on the cheapness of labour and on a consequent disregard for productivity. Labour productivity is related to patterns of demand and range of choice: the more variable the former and the larger the latter, the greater the tension between productivity and quality. In an examination of the cyclical nature of consumer demand, Riley (1981) argues that a move towards 'budget' service products gradually de-skills the industry because, when the upturn comes and higher standards are demanded, the capacity of the industry to respond quickly is not there: learning trails have disappeared. By this process, skill levels ratchet downwards.

\section{The difficulties with generic practices}

Modern approaches to HRM are founded on 'good practice'. U nfortunately, as examples tend to come from high-tech industries, this makes the practices easy to dismiss as inapplicable. H owever, even for those who try to implement them, there is one big problem to overcome. High-tech companies have a vested interest in keeping and developing their staff, and the case for that in tourism and hospitality is not strong. Failte Ireland (2005) identifies the commonly occurring good practices as: flexibility, participation, performance management, recognition, reward, communication, learning and development and empowerment. Although Bolton and Houlihan (2007) argue that these are merely processes imposed by management and have little to do with the individual, the criticism does not deny that the actual benefits are worthwhile. The point about these practices is they work as a 'bundle', not as a set of pick-and-mix features and that is what is problematic for tourism and hospitality. For example, even though it makes economic sense to use functional flexibility as well as numerical flexibility, efforts to implement it fall short. There is no inclination on the part of managers to substitute training for market flexibility (A rulampalam and Booth, 1998). H igh amongst the barriers to functional flexibility is the employee's need for an occupational identity. The effect is to maintain occupational rigidity within firms, with people changing occupations through changing employers; the labour market again acting as a change and learning agent. Although there have been serious attempts at instituting modern HRM, they have not been comprehensive (Kelliher and Riley, 2003; Cho et al, 2006). Kelliher and Riley (2002) show efforts being made to implement 
flexibility schemes and point out the obvious material benefits to employers. Their case studies also show how much sheer effort is needed to keep them going. The evidence of implementation is patchy ( $K$ nox and $W$ alsh, 2005) and there are examples of HRM being ignored completely because of the ready supply of cheap labour (Davidson et al, 2006).

It could be argued that the tourism and hospitality industry has not looked closely or systematically at functional flexibility. The real-life examples are usually the result of local initiatives and happen organically. Brusco et al (1998) point out that schemes do not need to involve high rates of substitutability to achieve optimum results. They make the important point that placing a value on flexibility allows all the options to be considered. In their argument, it is possible to be 'too flexible'. Flexibility comes in many forms, but if functional is the valued form, then the effect of this is to place a higher value on the propensity of an individual to be flexible than on any residual knowledge or skill they have accumulated. Within this perspective, the value of knowledge and skill is only its transferability. This, in turn, feeds back into the market and to human resource recruitment practices. To change from market to institutionalized flexibility requires the concept of functional flexibility to the valued. W hat brings about this change is not easy to see when labour is plentiful and cheap. What motives would management have? One motive might be the degree of emphasis on quality as against pure output and the degree to which such quality is attached to human capital. The relationship of human capital to quality is problematic because productivity and quality are difficult bedfellows, presenting managers with a conundrum. In this argument, the concern for quality is said to engender policies that attempt to retain staff on the grounds that continuity equates with higher quality. Even accepting this motive, the question of exactly how to implement a scheme remains. W hat is required is for managers to see work in tourism and hospitality as a set of processes that are interdependent and require shared knowledge (Smith, 1994; Feldman and Pentland, 2003). It is giving true value to the idea that things work because employees have knowledge and skill beyond their tasks, which facilitates the idea of human resource development. This perspective sees work in the form of a relational team where some of each individual's knowledge has the function of cooperation; it might even be its sole purpose. It is a mature view of modern organizations which the industry has not recognized.

\section{Discussion}

The central idea developed in this paper is that attitudes and structure can be mutually reinforcing and, consequently, there is a sustaining relationship between the nature of jobs, the valuation of skill by managers, the value to the worker of occupational identity and the structure of the labour market. In the case of tourism and hospitality, the valuation of skill by management exerts a strong influence on the configuration of HRM to be founded on a weak ILM, and consequently sustains the rigid occupational structures that exist both within firms and in the labour market. Whether the occupation is valued in a unionized job evaluation environment, such as airlines, or set solely by market forces, the result is a rigid occupational structure which breeds stable 
occupational identities and hierarchies. One explanation for this sustaining influence might be that there is a tradition of managers having the same technical knowledge as the workforce, which serves to reinforce the attitude towards skill. It may well be that managers have a low evaluation of technical skills because they are familiar with them; it is a question often asked but rarely answered in the job evaluation literature. Sharing the same knowledge base might well be the basis of good employee relations within the industry irrespective of HRM, but it presents a problem for modernization.

There are two ways forward for HRM in tourism and hospitality; one is succumbing to the tide of bureaucratic administration, made easier by IT (Grimshaw et al, 2002). In many respects, this would have advantages for employees as it emphasizes employment and hygiene factors over work and motivation incentives. However, technological and economic determinism will not make this easy. The other is to take a serious look at functional flexibility. In this respect, management has a number of options and problems to consider. These include the following:

- To accept that there are limits to technological substitution.

- To accept that although productivity can be improved by systems built around teamwork, that too has a finite opportunity because, ultimately, the team is subject to the same fluctuations in demand as the individual.

- To accept that throwing bodies at good service lasts only as long as labour is cheap.

- To accept that asking people to work harder when human capital is separated from productivity is meaningless.

- To accept that people have knowledge beyond their task and that there is such a thing as knowledge that works only if it is shared, and that exploring this route could be productive.

In these circumstances, having multi-skilled employees (irrespective of level of skill) who can move across services in line with consumer demand is an option with some advantages. However, examples show that, for manual and customer service work, it devel ops from the bottom up but does not last because of the energy needed to sustain it. The choice to be flexible is not one to be left to local managers; it is a strategic decision with implications for managerial resources (Wright and Snell, 1998).

The above analysis is a pessimistic view and one which neglects the efforts of practitioners who are implementing 'good practice' (N ickson, 2007). H owever, for any major change to take place in HRM, there has to be a good economic reason for wanting a stable workforce. The current situation suggests that both skilled and unskilled workers are valued in the same way. The alternatives are, on the one hand creating two types of ILM within the same workforce or pushing for a stronger internal market: this is the central strategic issue of HRM in tourism and hospitality. In respect of the model, the argument is not that the status quo is maintained by a collective organization inertia, but that it is the result of the unchanging nature of jobs and the normative attitudes towards skill that extend from that. One message from this analysis of tourism economics is that although the normal macro approaches to productivity apply, they are unlikely to capture the finer variations of demand that are the main influence on labour productivity. To a degree, productivity studies 
underestimate the extent of really short-term variation and its influence; the devil is very much in the detail.

\section{References}

Adams, T., and McQuillan, K. (2000), 'N ew jobs, new workers? Organizational restructuring and management hiring practices', Relations Industrielles/Industrial Relations, Vol 55, No 3, pp 391413.

Arnault, E.J., Gordon, L., Joines, D.H., and Phillips, G.M. (2001), 'An experimental study of job evaluation and comparable worth', Industrial Relations Review, Vol 54, No 34, pp 806-815.

A rulampalam, W., and Booth, A. (1998), 'Training and labour market flexibility: is there a tradeoff?' B ritish J ournal of Industrial Relations, Vol 36, No 4, pp 521-536.

Blount, Y., Castleman, T., and Swatman, P.M. (2005), 'E-commerce, human resource strategies and competitive advantage; two Australian banking case studies', International Journal of Electronic Commerce, Vol 9, No 3, pp 73-89.

Bolton, S., and Houlihan, M. (2007), 'Beginning the search for $\mathrm{H}$ in the HRM', in Bolton, S., and Houlihan, M., eds, Searching for the H uman in H uman R esource M anagement: Theory, Practice and Workplace Contexts, Palgrave, Basingstoke, pp 1-28.

Booth, A.L., and Snower, D.J. (1996), 'Introduction: does the free market produce enough skills?', in Booth, A.L., and Snower, D.J., eds, A cquiring Skills: M arket Failures, Their Symptoms and Policy Response, Cambridge Centre for Policy Research, Cambridge.

Brusco, M.J., Johns, T., and Reed, J.H. (1998), 'Cross-utilization of a two-skilled workforce', International Journal of Operations and Production M anagement, Vol 18, No 6, pp 555-564.

Caldwell, R. (2004), 'R hetoric, facts and self-fulfilling prophecies: exploring practitioners' perceptions of progress in implementing $\mathrm{HRM}^{\prime}$ ', Industrial Relations J ournal, Vol 35, N o 3, pp 196215.

Cho, S., Woods, S., Jang, S., and Erdern, M. (2006), 'Measuring the impact of human resource practices on hospitality firms' performance', International J ournal of $\mathrm{H}$ ospitality M anagement, $\mathrm{Vol}$ 25, N 0 2, pp 262-277.

Cully, M . (2002), 'T he cleaner, the waiter, the computor operator: job change 1986-2001', A ustralian Bulletin of Labour, Vol 28, No 3, pp 141-162.

Darrah, C. (1994), 'Skill requirements at work: rhetoric versus reality', Work and Occupations, Vol 21, No 1, pp 4-84.

Davidson, M., Guilding, C., and Timo, N . (2006), 'Employment, flexibility and the labour market practices of domestic and M N C chain luxury hotels in Australia: where has accountability gone?', International Journal of $\mathrm{H}$ ospitality M anagement, Vol 25, No 2, pp 193-210.

Doeringer, P.B., and Piore, M. (1971), Internal Labor M arkets and M anpower A nalysis, $H$ eath, Lexington, MA.

Failte I reland (2005), 'A human resource development strategy for I rish tourism', Competing Through People, 2005-2012, Failte Ireland, Dublin.

Feldman, M.S., and Pentland, B.T. (2003), 'Reconceptualizing organizational routines as a source of flexibility and change', Administrative Science Quarterly, Vol 48, No 1, pp 94-118.

Grimshaw, D., Cooke, F.-L., Grugulis, I., and Vincent, S. (2002), 'N ew technology and changing organisational forms: implications for managerial control and skills', N ew Technology, W ork and Employment, Vol 17, No 3 pp 186-203.

H abir, A.D., and Larasati, A.B. (1999), 'H uman resource management as competitive advantage in the new millennium', International J ournal of M anpower, Vol 20, No 8, pp 548-563.

Hage, J. (1989), 'The sociology of traditional economic problems; products and labour markets', Work and Occupations, Vol 16, No 4, pp 416-445.

Israel, A.A. (2007), 'Effectiveness and efficiency of managers: are they doing what they can or all they can?', Tourism E conomics, Vol 13, No 2, pp 181-195.

K ang, S.-C., Morris, S.S., and Snell, S.A.S. (2007), 'Relational archetypes, organizational learning, and value creation: extending the human resource architecture', A cademy of M anagement Review, Vol 32, No 1, pp 236-256.

Kelliher, C., and Riley, M. (2002), 'Making functional flexibility stick: an assessment of the outcomes for stakeholders', International J ournal of Contemporary H ospitality M anagement, Vol 14, No 5, pp 237-242. 
Kelliher, C., and Riley, M. (2003), 'Beyond efficiency: some by-products of functional flexibility', Service Industries J ournal, Vol 23, No 4, pp 98-113.

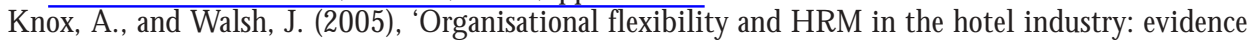
from Australia', Human R esource M anagement J ournal, Vol 15, No 1, pp 57-75.

Ladkin, A., and Riley, M. (1996), 'M obility and structure in the career paths of UK hotel managers: a labour market hybrid of the bureaucratic model?', Tourism M anagement, Vol 17, No 6, pp 443452.

Lepak, D.P., and Snell, S.A. (1999), 'The human resource architecture: toward a theory of human capital allocation and development', A cademy of M anagement Review, Vol 24, No 1, pp 31-48.

Levision, D., Ritter, J.A., Stock, R., and Anker, R. (2002), 'Distribution of income and job opportunities: normative judgements from four continents', International Labour R eview, Vol 141, No 4, pp 387-411.

Lui, A., and Wall, G. (2006), 'Planning tourism employment: a developing country perspective', Tourism M anagement, Vol 27, No 1, pp 159-170.

Maillat, D. (1984), 'Mobility channels: an instrument for analysis and regulating local labour markets', International Labour Review, Vol 130, No 3, pp 349-362.

Michie, J., and Sheehan, M. (2005), 'Business strategy, human resources, labour market flexibility and competitive advantage', International J ournal of H uman Resource M anagement, Vol 16, No 3, pp 445-464.

$\mathrm{N}$ ickson, D. (2007), H uman R esource M anagement for the H ospitality and Tourism Industries, ButterworthH einemann, Oxford.

N ickson, D., and W arhurst, C. (2007), 'Open Pandora's box: aesthetic labour and hospitality', in Lashley, C., Lynch, P., and M orrison, A., eds, H ospitality. A Social Lens, Elsevier, Oxford, pp 155172.

N ordhaug, O. (2004), 'Contributions to an economic theory of human resource management', H uman Resource M anagement Review, Vol 14, N o 4, pp 383-393.

Payne, J. (2000), 'The unbearable lightness of skill: the changing meaning of skill in UK policy discourses and some implications for education and training', Journal of Education Policy, Vol 15, No 3, pp 353-369.

Penn, R., Rose, M., and Rubery, J. (1994), Skill and Occupational Change, Oxford University Press, Oxford.

Phillips, M.E. (1996), 'Industrial mindsets: exploring the culture of two macro-organizational settings', in Meindl, J.R., Stubbart, C., and Porac, J.F., eds, Cognition Within and Between Organizations, Sage, London, pp 475-508.

Psacharopoulos, G. (1991), 'From manpower planning to labour market analysis', International L abour Review, Vol 130, No 4, pp 459-469.

Riley, M. (1981), 'Declining hotel standards and the skill trap', International Journal of Tourism M anagement, Vol 2, No 2, pp 95-104.

Riley, M. (1990), 'The labour retention strategies of UK hotel managers', Service Industries J ournal, Vol 10, No 3, pp 116-119.

Riley, M. (1993), 'Back to the future: lessons from free market experience', Employee Relations, Vol 15 , No 2, pp 20-28.

Riley, M. (1999), 'Re-defining the debate on hospitality productivity', Tourism and Hospitality Reearch, Vol 1, No 2, pp 182-186.

Riley, M., and Szivas, E. (2003), 'Pay determination: a socio-economic framework', A nnals of Tourism Research, Vol 30, No 2, pp 446-464.

Riley, M., Gore, J., and K elliher, C. (2000), 'Economic determinism and human resource management practice in the hospitality and tourism industry', Tourism and H ospitality Research, Vol 2, No 2, pp 118-128.

Riley, M., Ladkin, A., and Szivas, E. (2002), Tourism Employment A nalysis and Planning, Channel View, Clevedon.

Rosen, S. (1972), 'Learning and experience in the labour market', J ournal of H uman R esources, Vol 7, No 4, pp 326-342.

Rousseau, D.M. (1995), P sychological Contract in Organizations: U nderstanding W ritten and U nwritten A greements, Sage, London.

Simms, J., Riley, M., and Hales, C. (1988), 'Examination of the concept of internal labour markets in UK hotels', International Journal of Tourism Management, Vol 9, No 3, pp 3-12.

Smith, V. (1994), 'Institutionalizing flexibility in a service firm', W ork and Occupations, Vol 21, No 3, pp 284-307. 
Spell, C.S. (2001), 'Organizational technologies and human resource management', H uman R elations, Vol 54, No 2, pp 193-21.

Spender, J.C. (1989), Industry Reapes, Blackwell, Oxford.

Stinchcombe, A.L. (1963), 'Some empirical consequences of the D avis-M oore theory of stratification', A merican Sociological Review, Vol 38, No 5, pp 805-808.

Storey, J. (1995), N ew Perspectives on H uman Resource M anagement, Routledge, London.

Tompkins, J. (1987), 'Comparable worth and job evaluation validity', Public A dministration Review, Vol 47, No 3, pp 254-258.

Townley, B. (1993), 'Foucault, power/knowledge, and its relevance for human resource management', A cademy of Management Review, Vol 18, No 3, pp 518-545.

Truss, C., Gratton, L., Hope-H ailey, V., M CG overn, P., and Stiles, P. (1997), 'Soft and hard models of human resources management: a reappraisal', Journal of M anagement Studies, Vol 34, N O 1, pp 53-73.

Wright, P.M ., and Snell, S.A. (1998), 'Toward a unifying framework for exploring fit and flexibility in strategic human resource management', A cademy of M anagenent Review, Vol 23, No 4, pp 756772. 